\title{
THE INFLUENCE OF SODIUM NITRITE CONCENTRATION IN INHIBITOR PROTECTION OF STRUCTURAL ELEMENTS WORKING IN AGGRESSIVE ENVIRONMENTAL CONDITIONS
}

\author{
Jacek MENDALA, Jarosław KOZUBA \\ Silesian University of Technology, Katowice, Poland, EU, \\ jacek.mendala@polsl.pl, jaroslaw.kozuba@polsl.pl
}

https://doi.org/10.37904/metal.2019.895

\begin{abstract}
The durability of materials working in aggressive environments is mostly important in the design of structures and devices. Corrosion destruction is one of the main causes of material losses, reduced efficiency and safety of their use. Corrosion cannot be completely eliminated but it can be significantly reduced by using different methods of protection. Proper design of structures working in aggressive environments, the use of protective coatings or environmental modification significantly reduces the rate of corrosion. Corrosion inhibitors are also used to protect the structural elements. An addition of a small amount of a chemical compound or a mixture of corrosion inhibitor compounds results in a significant reduction of the corrosion rate. To select a proper corrosion inhibitor and proper concentration for a specific corrosion system, laboratory tests are carried out. The article presents the results of research on determining the effect of inhibitor - $\mathrm{NaNO}_{2}$ sodium nitrite - on the dissolution kinetics of model constructional steel in water environment and in an aqueous sodium chloride solution. The influence of inhibitor concentration in the range of $0.5-2.5 \%$ on the corrosion rate of steel in a $5 \%$ solution of sodium chloride was estimated by assessing unit changes in mass and corrosion rates. The effectiveness of inhibitors was determined using the protection factor $v$ and the inhibitor efficiency $E_{f}$.
\end{abstract}

Keywords: Corrosion, corrosion inhibitor, sodium nitrite, anodic inhibition

\section{INTRODUCTION}

Corrosion is the process of gradual destruction of a material under the influence of chemical or electrochemical action of the environment. Among all types of corrosion, general corrosion causes the largest losses in mass of metal, but is also the easiest to detect and combat. The phenomenon of corrosion cannot be completely eliminated, but its effects can be significantly reduced [1,2]. The basic methods of preventing or reducing corrosion include: proper selection of materials, design, cathodic protection, application of protective coatings and inhibitor protection [3] The simplest method of corrosion control is the selection of materials for structural elements with appropriate chemical composition and properties adequate to the expected operating conditions $[1,3]$. Another method is an application of rational design principles which can eliminate many corrosion problems and reduce the time and costs associated with corrosion maintenance and repair [3]. Cathodic protection is an electrical method to reduce corrosion rate of metallic structures in electrolytes such as soil or water $[4,5]$. To achieve the protection, the impressed current cathodic protection (ICCP) system and the sacrificial anodes cathodic protection (SACP) system are used [3]. Corrosion control by anodic protection is known from the literature [1] but currently it is rarely used due to high restrictions. One of the most important methods of protection against corrosion is the application of coatings. The purpose of coatings is to isolate the material of which a structural element is made from an aggressive corrosive environment $[6,7]$. Coatings can be metallic (zinc-based coatings are very popular in functional engineering) or non-metallic (organic or inorganic) $[7,8]$. In many structures operating in aggressive environments, where there is no possibility of protecting the metal with coatings (e.g. inside the pipeline) or where coatings do not provide sufficient protection, e.g. in closed circuits of heating or cooling systems (where coatings hinder heat exchange), a reduction in losses caused by corrosion can be achieved through the application of inhibitor protection, i.e. the introduction of special chemicals into the environment. 
Corrosion inhibitors are defined as such chemical compounds or mixtures of several compounds whose small addition to the corrosive environment reduces the corrosion rate of the metal in contact with that environment. Inhibitor protection can be used as a stand-alone metal corrosion protection as well as in a combination with other protection methods, e.g. with cathodic or coating protection. Inhibitors are used in a number of fields of technology: in the automotive, aerospace, machine building, electronics, petrochemical and food processing industries $[4,5,9,10]$.

Corrosion inhibitors can be both inorganic and organic compounds. In terms of the mechanism of their electrochemical action, inhibitors can be divided into cathodic, anodic and mixed. Inorganic cathodic inhibitors decrease the corrosion rate of metals by reducing the cathodic surface area, increasing overvoltage in the cathodic process or reducing the oxygen content [5]. They include: $\mathrm{Ca}\left(\mathrm{HCO}_{3}\right)_{2}, \mathrm{ZnSO} 4, \mathrm{ZnCl}_{2}$ and $\mathrm{BeCl}_{2}$, as well as heavy metal cations: $\mathrm{As}^{3+}, \mathrm{Bi}^{3+}$ and $\mathrm{Sb}^{3+}$. Anodic inhibitors increase the anodic polarity of the metal and as a result, the corrosive potential of the system shifts in the positive direction. This group includes chemical compounds with a covering effect $\left(\mathrm{NaOH}, \mathrm{Na}_{2} \mathrm{CO}_{3}\right.$ and phosphates) or oxidizing effect (passivators: chromates, nitrites), where the anion is usually the active group of these compounds. Anions migrate to the metal surface and in favourable conditions passivate it, often with the participation of dissolved oxygen $[1,5]$. The effectiveness of corrosion inhibitors depends on the influence of internal and external factors of metal corrosion, the most important of which is the corrosive environment reaction and inhibitor concentration $[4,5]$. The paper presents the results of research on the influence of the concentration of sodium nitrite inhibitor, $\mathrm{NaNO}_{2}$, in an aqueous solution of sodium chloride on the dissolution kinetics of model structural steel.

\section{MATERIAL AND EXPERIMENTAL PROCEDURE}

Tests were performed on samples with dimensions: $5 \mathrm{~cm} \times 5 \mathrm{~cm} \times 0.3 \mathrm{~cm}$ made from general purpose unalloyed structural steel, S235JRG2. The chemical composition of the steel is presented in Table 1.

Table 1 Chemical composition of the S235JRG2 steel

\begin{tabular}{|c|c|c|c|c|c|}
\hline \multicolumn{7}{|c|}{ Content of an element (wt. \%) } \\
\hline C & Mn & P & S & N & Fe \\
\hline 0.17 & 1.4 & 0.03 & 0.03 & 0.009 & rest \\
\hline
\end{tabular}

Five corrosive solutions were made in laboratory beakers. The first one was distilled water only, while $\mathrm{NaCl}$ was added to the others, so as to produce a $5 \%$ aqueous solution. This solution was the basis for determining the effectiveness of the inhibitor in the environment containing sodium chloride. The remaining beakers were treated with an addition of a corrosion inhibitor, namely sodium nitrite, $\mathrm{NaNO}_{2}$, in the amounts of $0.5 \%, 1.5 \%$ and $2.5 \%$. A summary of the solutions used in the tests is provided in Table 2.

Table 2 A summary of corrosive solutions used in the tests

\begin{tabular}{|c|c|c|}
\hline No. of sample & Corrosive solutions & Inhibitor addition \\
\hline 1 & $\mathrm{H}_{2} \mathrm{O}$ (distilled water) & - \\
\hline 2 & $\mathrm{H}_{2} \mathrm{O}+5 \% \mathrm{NaCl}$ & - \\
\hline 3 & $\mathrm{H}_{2} \mathrm{O}+5 \% \mathrm{NaCl}$ & $0.5 \% \mathrm{NaNO}_{2}$ \\
\hline 4 & $\mathrm{H}_{2} \mathrm{O}+5 \% \mathrm{NaCl}$ & $1.5 \% \mathrm{NaNO}_{2}$ \\
\hline 5 & $\mathrm{H}_{2} \mathrm{O}+5 \% \mathrm{NaCl}$ & $2.5 \% \mathrm{NaNO}_{2}$ \\
\hline
\end{tabular}

Sodium nitrite is an inhibitor commonly used to protect a number of metals except zinc and copper alloys. The protective effect of nitrites consists in the formation of an oxide layer according to equation (1): 


$$
2 \mathrm{Fe}+\mathrm{NaNQ}+2 \mathrm{H}_{2} \mathrm{O} \rightarrow \mathrm{Fe}_{2} \mathrm{O}_{3}+\mathrm{NaOH}+\mathrm{NH}_{3}
$$

Nitrites are effectively used as steel corrosion inhibitors in aqueous solutions with $\mathrm{pH}$ greater than 5 , and the protective concentration in water installations (aerated solutions) at room temperature is ca. $10^{-2} \mathrm{~mol} \cdot \mathrm{m}^{-3}$. A higher inhibitor concentration is required in deaerated systems and at higher temperature. The presence of other anions in the solution also requires an increased nitrite concentration.

After calculating the total area of the steel samples, they were placed in the prepared solutions. Macroscopic and gravimetric tests were carried out with the use of laboratory scale WAX 60/160 to an accuracy of 0.00001 $\mathrm{g}$ after $24,48,96,144,216$ and $288 \mathrm{~h}$ of test duration. After each test cycle, the samples were taken from the solution and loose, poorly bound to the substrate corrosion products were removed over the beaker and dried with compressed air. Mass was measured and photographic documentation was made, after which the samples were immersed again. On the basis of gravimetric tests, unit changes in mass of the samples during the test were determined and the corrosion rate was calculated (equation 2) [5]:

$$
C_{R}=\frac{\Delta m}{A \cdot t}\left(\mathrm{mg} \cdot \mathrm{cm}^{-2} \cdot \mathrm{h}^{-1}\right)
$$

where:

$$
\begin{aligned}
& \Delta m \text { - mass loss }(\mathrm{mg}), \\
& A \text { - sample area }\left(\mathrm{cm}^{2}\right), \\
& t \text { - time of test }(\mathrm{mm}) .
\end{aligned}
$$

The gravimetric tests also allowed determination of the effectiveness of the inhibitor by calculating the protection factor, $v$ (equation 3 ), and the inhibitor efficiency, $E_{f}$ (equation 4) [4,5]:

$$
\begin{aligned}
& v=\frac{C_{R o}}{C_{R i}} \\
& E_{f}=\frac{C_{R o}-C_{R i}}{C_{R o}} \cdot 100 \%
\end{aligned}
$$

where:

$$
\begin{aligned}
& C_{R o} \text { - corrosion rate of metal without inhibitor }\left(\mathrm{mg}_{\mathrm{cm}} \mathrm{cm}^{-2} \cdot \mathrm{h}^{-1}\right) \text {, } \\
& C_{R i} \text { - corrosion rate of metal with inhibitor }\left(\mathrm{mg} \cdot \mathrm{cm}^{-2} \cdot \mathrm{h}^{-1}\right) \text {. }
\end{aligned}
$$

\section{RESULTS}

Based on macroscopic observation and gravimetric examination, it is possible to determine the course of the corrosion process and parameters describing the effectiveness of the inhibitor in a corrosive environment. Gravimetric tests are effective in the case of surface or general corrosion.

On the basis of the macroscopic evaluation it can be stated that the corrosion process occurring on the surface of samples is varied and depends on the corrosive environment and the amount of corrosion inhibitor in the solution. Analysis of the examined samples allowed observation of changes which occurred on the metal surface (Figure 1). Inhibitor protection for a sample in the environment of sodium chloride with a $2.5 \%$ corrosion inhibitor content (sample 5) was the most effective after 288 hours of test time, with no corrosion products observed on the sample surface. Slightly worse results of macroscopic evaluation were observed for sample no. 4 , placed in a $5 \% \mathrm{NaCl}$ solution with an addition of $1.5 \% \mathrm{NaNO}_{2}$. Sample no. 3 
( $5 \%$ sol. $\mathrm{NaCl}+0.5 \% \mathrm{NaNO}_{2}$ ) did not provide sufficient protection, and corrosion products appeared already after $48 \mathrm{~h}$ of testing. The largest amount of corrosion products was observed on samples placed in corrosive environments without a corrosion inhibitor (water environment and sodium chloride solution - samples no. 1 and 2). The corrosion products that appeared on the metal samples were loosely packed in the surface, making them easy to remove.

a)
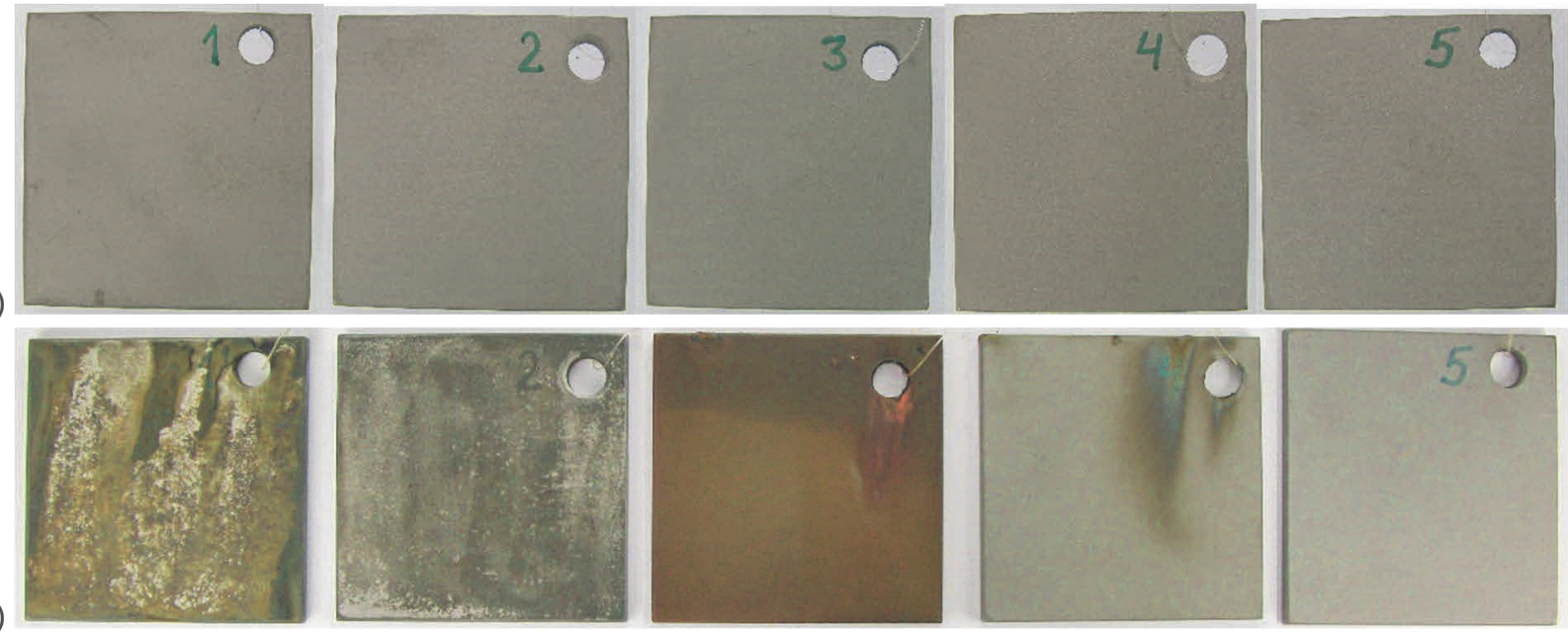

Figure 1 The surface appearance of the samples for the tests: a) before the test,

b) after the corrosion test ( $288 \mathrm{~h}$ )

Gravimetric tests allowed a comparison of the loss of mass of samples exposed to corrosive environment with and without a corrosion inhibitor. Based on the data shown in Table 3 and a graphical interpretation of the relationship between unit changes in the mass of samples placed in different environments for the duration of the test (Figure 2a), it can be affirmed that the changes are linear. This refers to all samples present in the tested corrosive environments. For the sample immersed in the solution with the highest corrosion inhibitor concentration, the mass loss was the lowest and after $288 \mathrm{~h}$ of the test it amounted to $0.11652 \mathrm{mg} \cdot \mathrm{cm}^{-2}$. The results of the tests in relation to the test time allowed calculating the corrosion rate based on the equation (2), which is presented in Table $\mathbf{3}$ and in Figure $\mathbf{2 b}$.

Table 3 Unit mass changes and corrosion rate of the samples during the test

\begin{tabular}{|c|c|c|c|c|c|c|c|c|c|c|}
\hline Parameter & & Unit mas & ss change & $\left(\mathrm{mg} \cdot \mathrm{cm}^{-2}\right)$ & & & Corrosio & $\mathrm{n}$ rate $(\mathrm{mg}$ & $\left(\mathrm{cm}^{-2} \cdot \mathrm{h}^{-1}\right)$ & \\
\hline Environment & $\mathrm{H}_{2} \mathrm{O}$ & $\begin{array}{c}5 \% \text { sol. } \\
\mathrm{NaCl}\end{array}$ & $\begin{array}{c}5 \% \text { sol. } \\
\mathrm{NaCl}+ \\
0.5 \% \\
\mathrm{NaNO}_{2} \\
\end{array}$ & $\begin{array}{c}5 \% \text { sol. } \\
\mathrm{NaCl}+ \\
1.5 \% \\
\mathrm{NaNO}_{2} \\
\end{array}$ & $\begin{array}{c}5 \% \text { sol. } \\
\mathrm{NaCl}+ \\
2.5 \% \\
\mathrm{NaNO}_{2} \\
\end{array}$ & $\mathrm{H}_{2} \mathrm{O}$ & $\begin{array}{c}5 \% \text { sol. } \\
\mathrm{NaCl}\end{array}$ & $\begin{array}{c}5 \% \text { sol. } \\
\mathrm{NaCl}+ \\
0.5 \% \\
\mathrm{NaNO}_{2} \\
\end{array}$ & $\begin{array}{c}5 \% \text { sol. } \\
\mathrm{NaCl}+ \\
1.5 \% \\
\mathrm{NaNO}_{2} \\
\end{array}$ & $\begin{array}{c}5 \% \text { sol. } \\
\mathrm{NaCl}+ \\
2.5 \% \\
\mathrm{NaNO}_{2} \\
\end{array}$ \\
\hline Time $\backslash$ No. & 1 & 2 & 3 & 4 & 5 & 1 & 2 & 3 & 4 & 5 \\
\hline $24 \mathrm{~h}$ & -0.09537 & -0.15250 & -0.05699 & -0.01988 & -0.00771 & 0.00397 & 0.00635 & 0.00237 & 0.00083 & 0.00032 \\
\hline $48 \mathrm{~h}$ & -0.19092 & -0.30159 & -0.11935 & 3977 & -0.01542 & 00398 & 00628 & 00249 & 0.00083 & 0.00032 \\
\hline $96 \mathrm{~h}$ & -0.39331 & -0.59136 & -0.25770 & -0.06377 & -0.02617 & 0.00410 & 0.00616 & 0.00268 & 0.00066 & 0.00027 \\
\hline $144 \mathrm{~h}$ & -0.59678 & -0.86858 & -0.38566 & -0.09476 & -0.04302 & 0.00414 & 0.00603 & 0.00268 & 0.00066 & 0.00030 \\
\hline $216 \mathrm{~h}$ & -0.92412 & -1.28736 & -0.57463 & -0.17859 & -0.07977 & 0.00428 & 0.00596 & 0.00266 & 0.00083 & 0.00037 \\
\hline $288 \mathrm{~h}$ & -1.25146 & -1.70615 & -0.76361 & -0.26242 & -0.11652 & 0.00435 & 0.00592 & 0.00265 & 0.00091 & 0.00040 \\
\hline
\end{tabular}

During the corrosion test, the sample placed in the $5 \% \mathrm{NaCl}$ solution corroded at the highest rate, while the sample in the water environment corroded at a rate lower by ca. $50 \%$. The use of the $\mathrm{NaNO}_{2}$ inhibitor in the 
amount of $0.5 \%$ in the investigated corrosive environment decreased the corrosion rate by ca. $100 \%$ compared to this environment without a corrosion inhibitor. However, such an amount of the inhibitor is not satisfactory, since the macroscopic and gravimetric analysis showed adverse corrosion changes. The use of $1.5 \%$ sodium nitrite brings an already satisfactory effect in terms of the quantity of corrosion products, and based on the gravimetric evaluation and the calculated corrosion rate, it can be concluded that the quantity has decreased by about six times in relation to the same environment without the inhibitor. The lowest corrosion rate (by a dozen or so times) was observed for the sample placed in a $5 \% \mathrm{NaCl}$ solution with an addition of $2.5 \% \mathrm{NaNO}_{2}$.

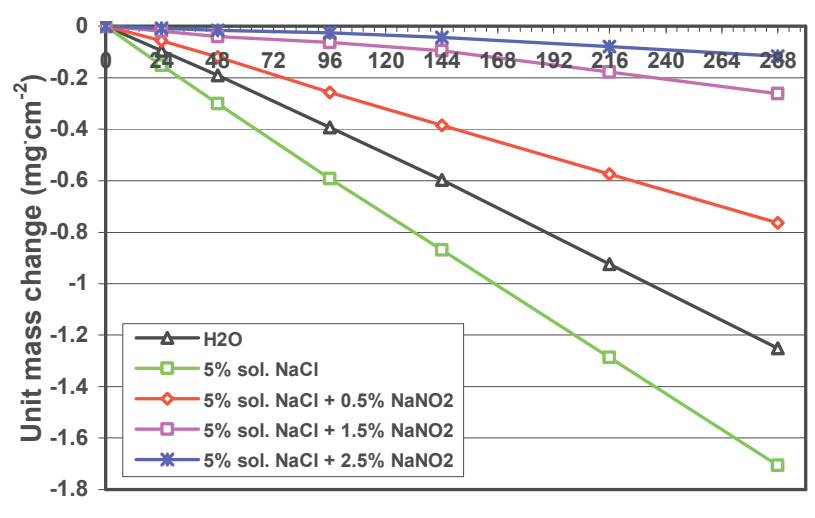

a)

Time (h)

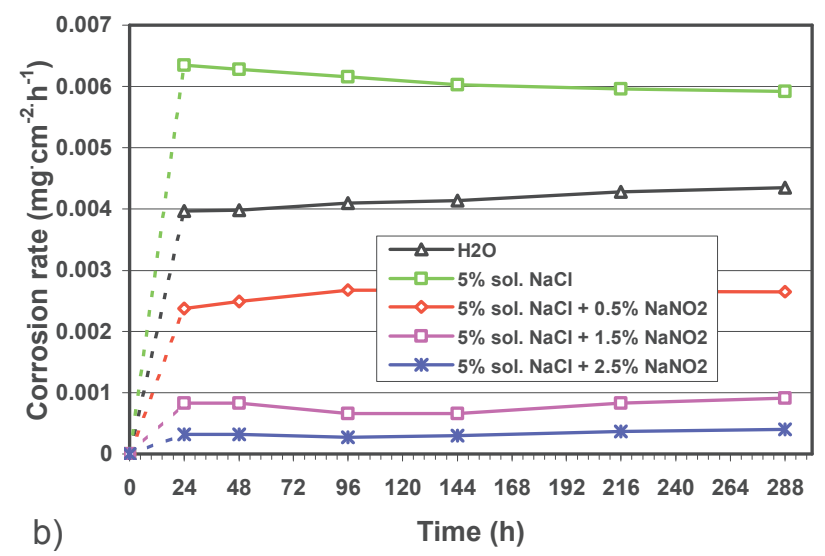

Figure 2 Effect of corrosion inhibitor $\mathrm{NaNO}_{2}$ concentration in the tested environment on: a) unit mass changes, b) corrosion rate

The effectiveness of the inhibitor may be evaluated by measuring the protection factor, $v$, calculated after examining the changes in mass of the sample immersed in the solution without the inhibitor, and exactly in the same environment and under the same conditions but with the inhibitor (equation 3). The studies showed that the best protection was achieved with a $2.5 \%$ content of the inhibitor (Table 4). The mean value of the protection factor was 19 , which indicates that the protection increased by such a multiplication factor compared to the tested environment without the inhibitor. Calculation of the effectiveness of inhibitor $E_{f}$ (equation 4 ) for the individual samples showed the dependence of $\mathrm{NaNO}_{2}$ concentration on protective properties. The best, $95 \%$ effectiveness was observed for the sample placed in the solution with an addition of $2.5 \%$ inhibitor, and slightly worse results were obtained for the $1.5 \%$ (87 \%) concentration. The lowest effectiveness of $58 \%$ was obtained by the sample in the solution with a $0.5 \% \mathrm{NaNO}_{2}$ addition.

Table 4 The effectiveness of the $\mathrm{NaNO}_{2}$ inhibitor in the tested corrosive environment

\begin{tabular}{|c|c|c|c|c|c|c|}
\hline Parameter & \multicolumn{3}{|c|}{ Protection factor $v$} & \multicolumn{3}{c|}{ Inhibitor efficiency $\mathrm{E}_{f}(\%)$} \\
\hline Environment & $\begin{array}{c}5 \% \text { sol. } \mathrm{NaCl}+ \\
0.5 \% \mathrm{NaNO}_{2}\end{array}$ & $\begin{array}{c}5 \% \text { sol. NaCl }+ \\
1.5 \% \mathrm{NaNO}_{2}\end{array}$ & $\begin{array}{c}5 \% \text { sol. NaCl}+ \\
2.5 \% \mathrm{NaNO}_{2}\end{array}$ & $\begin{array}{c}5 \% \text { sol. NaCl }+ \\
0.5 \% \mathrm{NaNO}_{2}\end{array}$ & $\begin{array}{c}5 \% \text { sol. } \mathrm{NaCl}+ \\
1.5 \% \mathrm{NaNO}_{2}\end{array}$ & $\begin{array}{c}5 \% \mathrm{sol} . \mathrm{NaCl}+ \\
2.5 \% \mathrm{NaNO}_{2}\end{array}$ \\
\hline Time $\backslash \mathrm{No}$. & 3 & 4 & 5 & 3 & 4 & 5 \\
\hline $24 \mathrm{~h}$ & 2.7 & 7.7 & 19.8 & 63 & 87 & 95 \\
\hline $48 \mathrm{~h}$ & 2.5 & 7.6 & 19.6 & 60 & 87 & 95 \\
\hline $96 \mathrm{~h}$ & 2.3 & 9.3 & 22.8 & 56 & 89 & 96 \\
\hline $144 \mathrm{~h}$ & 2.3 & 9.1 & 20.1 & 56 & 89 & 95 \\
\hline $216 \mathrm{~h}$ & 2.2 & 7.2 & 16.1 & 55 & 86 & 94 \\
\hline $288 \mathrm{~h}$ & 2.2 & 6.5 & 14.8 & 55 & 85 & 93 \\
\hline Average & 2.5 & 8 & 19 & 58 & 87 & 95 \\
\hline
\end{tabular}


It can also be stated that in the tests performed, the best anti-corrosion properties were found for the sample immersed in the solution with the highest, within the studied range, amount of corrosion inhibitor of sodium nitrite. The $2.5 \% \mathrm{NaNO}_{2}$ concentration provided effective protection for the S235JRG2 structural steel placed in a $5 \% \mathrm{NaCl}$ solution during the test.

\section{CONCLUSION}

Inhibitor protection of structures operating in aggressive environments is highly dependent on the concentration of the inhibitor. Too low a concentration may not be sufficient to provide adequate protection for the structure. However, too high a concentration, especially in the case of passivation inhibitors, can accelerate metal corrosion or cause pitting corrosion.

During the test, the corrosion products formed uniformly on the surface and were weakly bound to the substrate. Gravimetric tests allowed a comparison of unit changes in mass of metal samples exposed to different corrosive environments and the determination of the corrosion rate. The changes in mass are of a linear nature.

Analysing the effectiveness of the inhibitor, an addition of $1.5 \%$ sodium nitrite to the corrosive environment of a $5 \%$ sodium chloride solution results in a protection factor of 8 . Increasing the inhibitor content to $2.5 \%$ increases the protection factor to 19 . The calculated inhibitor effectiveness, which in this case was $95 \%$, also confirms its high efficiency.

\section{REFERENCES}

[1] McCAFFERTY, Edward, Introduction to Corrosion Science. Springer, New York, USA, 2009.

[2] PRZONDZIONO, Joanna, HADASIK, Eugeniusz, Walke, Witold, MENDALA, Jacek, Impact of sterilisation and strain hardening in drawing process on resistance to electrochemical corrosion of wires intended in cardiology. Arch. Metall. Mater., 2016, vol. 61, iss. 1, pp. 249-252, DOI: 10.1515/amm-2016-0046.

[3] BRYCKI, Bogumił E., KOWALCZYK, Iwona H., SZULC, Adrianna, KACZEREWSKA, Olga, PAKIET, Marta, Organic Corrosion Inhibitors, In: IntechOpen, Mahmood Aliofkhazraei, ed. Corrosion Inhibitors, Principles and Recent Applications, 2017, chapter 1, DOI: 10.5772/intechopen.72943.

[4] DARIVA, Camila G., GALIO, Alexandre F., Corrosion Inhibitors - Principles, Mechanisms and Applications. In: IntechOpen, Mahmood Aliofkhazraei, ed. Developments in Corrosion Protection, 2014, chapter 16, DOI: $10.5772 / 57255$.

[5] SASTRI, Vedula. S., Corrosion Inhibitors, Principles and Applications. Wiley, London, UK, 1998.

[6] MENDALA, Jacek, Liquid metal embrittlement of steel with galvanized coatings. IOP Conference Series-Materials Science and Engineering, 2012, vol. 35, no. 012002, DOI: 10.1088/1757-899X/35/1/012002.

[7] KANIA, Henryk, BIEROŃSKA, Marzena, Corrosion Resistance of Zn-31AIMg Coatings Obtained by Batch Hot Dip Method. Solid State Phenomena. 2014, vol. 212, pp. 167-172. DOI: 10.4028/www.scientific.net/SSP.212.167.

[8] KANIA, Henryk, Odporność korozyjna powłok otrzymanych w kąpieli ZnAl z dodatkiem Mg (in Polish). Przemysł Chemiczny. 2017, t. 96, no. 1, pp. 465-468. DOI: 10.15199/62.2017.2.39.

[9] PANDIARAJAN, Mp, RAJENDRAN, Susai, BAMA, J. Sathiya, RATHISH, Joseph, Sodium nitrite as corrosion inhibitor for mild steel in simulated concrete pore solution. Journal of Chemical and Pharmaceutical Research. 2015, vol. 7 (10S), pp. 120-126.

[10] HAYYAN, Maan, SAMEH, Shatha A, HAYYAN, Adeeb, ALNASHEF, Inas M., Utilizing of Sodium Nitrite as Inhibitor for Protection of Carbon Steel in Salt Solution. Int. J. Electrochem. Sci., 2012, vol. 7, pp. 6941-6950. 